\title{
PREREQUISITES AND PERCEIVED INFORMATION SYSTEM QUALITIES MODEL FOR MOBILE BANKING ADOPTION AMONG THE CUSTOMERS OF PRIVATE COMMERCIAL BANKS IN MYANMAR
}

\author{
Phyo Min Tun \\ Department of Information Technology, Assumption University, \\ Bangkok, Thailand \\ phyomintun.sg@gmail.com
}

Received: $31^{\text {st }}$ December 2020/ Revised: $18^{\text {th }}$ January 2021/ Accepted: $08^{\text {th }}$ April 2021

How to Cite: Tun, P. M. (2021). Prerequisites and perceived information system qualities model for mobile banking adoption among the customers of private commercial banks in Myanmar. Journal of ASEAN Studies, 9(1), 49-71, https://doi.org/10.21512/jas.v9i1.6899

\begin{abstract}
The research attempts to conjecture the prerequisites of perceived qualities of information system (IS) such as mobile banking (MB). The quantitative research was conducted and a total of 577 MB users of private commercial banks in Myanmar participated in the research. The results of the hypotheses were formulated by using partly exploratory factor analysis (EFA), partly confirmatory factor analysis (CFA), and structural equation modeling (SEM) techniques. The findings expose that device quality is an independent factor, and an antecedent of user interface design quality and system quality. The research also discloses that user interface design quality is a prerequisite of system quality and information quality. In the research, system quality and information quality are key factors affecting customers' intention to adopt MB. Further, the results confirm that system quality has a statistically significant effect on information quality. However, the effect of device quality on information quality is insignificant. It is expected that the research gives valuable insights for not only bank managers but also software engineers who are going to develop MB systems.
\end{abstract}

Keywords: mobile banking, information system, qualities, private banks, Myanmar.

\section{INTRODUCTION}

The inventions of advanced technology drive the retail banks to perform the rapid digital transformation of banking services and create a mobile environment that enables customers to perform financial transactions with minimum effort (Tam \& Oliveira, 2017). Therefore, the usage of mobile technology devices and innovative financial technologies (Fin- 
Tech) in financial institutions is inevitable. As a result of technological advancement, banks invent an information system (IS) based on the mobile app to assist their customers to interact with their services (Noh \& Lee, 2016). Mobile banking (MB) provides customers with extensive benefits such as conducting their financial transactions at anytime and anywhere. Moreover, MB supports the potential of increasing the effectiveness of payment methods and expanding the accessibility of traditional banking services by those who currently lack them. Being originally independent of location and time, MB provides cost-effective banking services and can play a crucial role, particularly in emerging countries. $\mathrm{MB}$ has extra advantages compared to traditional banking which allow the banks for minimizing cost, maximizing revenue, more market shares, higher brand loyalty, greater customer retention, and better customer experience (Jeong \& Yoon, 2013). Thus, banks are investing in developing MB continuously. However, the adoption rate is still under the expectation of banks since their customers still hesitate to use this technology.

The research attempts to disclose the underlying prerequisite qualities of the perceived IS qualities from DeLone and McLean (1992) information system success (ISS) model, which is one of the widely employed research models to verify the likelihood of the success of IS in the mobile commercial application landscape (Petter, DeLone, \& McLean, 2013). This empirical research is a first-time endeavor to discover the prerequisites of perceived IS qualities in MB context (Sharma \& Sharma, 2019; Damabi, Firoozbakht, \& Ahmadyan, 2018; Myo \& Hwang, 2017; Deventer, Klerk, \& Bevan-Dye, 2017; Tam \& Oliveira, 2017; Lokman et al., 2017; Zhou, 2012; Zhou, 2011; Lee \& Chung, 2009). Therefore, the research focuses on a comprehensive set of potential IS qualities that influence MB adoption. Two factors adapted from the ISS model of DeLone and McLean (1992), system quality and information quality, and two factors based on prior studies, device quality and user interface design quality, are employed to investigate the intention of users to adopt MB. Furthermore, the major objective of the research is to contribute to both theoretical and managerial issues concerning the relationships among the different quality aspects and the influence on the individual intention in MB adoption. Thus, the following research questions are needed to answer in this study:

$R Q 1$ : What are the underlying prerequisite IS qualities?

$R Q 2:$ What are the relationships between prerequisite and perceived IS qualities?

$R Q 3:$ Which perceived IS quality is more important than others in MB adoption?

\section{LITERATURE REVIEW}

Myanmar, an ASEAN country, had been mainly a cash-based economy due to the prolonged over controlling of financial policy by the central government since 1960. As a result of the Financial Institutions Law in 1990, several private commercial banks emerged. Nonetheless, the era of rising private commercial banks was short due to the banking crisis occurring in 2003, so the financial sector became fragile (Tun, 2020a). As a consequence of reforming economic policy in 2011, financial inclusion enabled conditions for the endeavor of re-establishing private banks (Turnell, 2011). There are currently 27 privately-owned domestic banks in Myanmar which dominate $67 \%$ of total bank assets in Myanmar (Hofmann, 2018). 
Among them, Kanbawza Bank (KBZ) is the largest private commercial bank which represents $41 \%$ of the private bank market share. Ayeyarwady Bank (AYA) is the second largest with $17 \%$ of the total, followed by Co-operative Bank (CB) with $11 \%$ of the total. Furthermore, only $25 \%$ of the Myanmar population has bank accounts according to the World Bank Report 2018. Besides, there are about 68,24 million mobile phone users in Myanmar and mobile network coverage is currently at $82 \%$. The majority of mobile phone users $(90 \%)$ are using the device with the android platform, while only $10 \%$ are using Apple IOS devices (Kemp, 2020). Therefore, the Central Bank of Myanmar (CBM) has granted private banks to operate mobile banking services since 2013. Although there are abundant facilitating conditions, MB adoption in Myanmar is relatively low compared to mobile phone users (Lwin, Ameen, \& Nusari, 2019).

The growth of m-commerce technologies transforms the way of banks and their customers conduct financial transactions, and mobile banking (MB) is one of them (AlBalawi \& Rehman, 2016). MB is a major mobile financial management service having similar functionality with internet banking (via computer) that is widely adopted by many customers to mainly check the account balance and process fund transfers (Gu, Lee, \& Suh, 2009). Similarly, Mahad et al. (2015) defined MB as the use of mobile smartphone devices to access banking tasks not only for transferring funds and monitoring account balances but also making bill payments and locating automated teller machines (ATM). Furthermore, MB can be assumed as a subset of electronic banking (e-banking) that refers to the transformation of accessing financial services from wired networks to wireless networks through a mobile device (Clarke III, 2001).

According to Yeo and Fisher (2017), MB is a more advanced financial technology than online banking with unique features such as narrow costs for usage, mobility, customization, and a broader scope of utilities. Moreover, MB has evolved from short message service (SMS) based banking to mobile applications installed in users' smartphone devices (Deventer, Klerk, $\&$ Bevan-Dye, 2017). MB offers private commercial banks' customers a variety of advantages of conducting financial services easily, effectively, quickly, and conveniently compared to accessing physical banks. In addition, MB is an application of m-commerce and an innovative method which facilitates business transactions via telecommunication channels by using mobile devices (Kim, Shin, \& Lee, 2009).

\section{THEORETICAL BACKGROUND}

DeLone and McLean (1992) proposed a model to measure IS success (Figure 1) based on the Theory of Communication by Shannon and Weaver (1949). The IS success model caught the concept of a communication system which is a mechanism of delivering and transferring information to the receivers. As a result, DeLone and McLean built a framework consisting of two major quality dimensions, system quality to measure technical success, and information quality to measure semantic success. Later, Seddon (1997) suggested modifying the D\&M ISS model for clarification since the original framework is confusing, and the use construct in the model is ambiguous. 


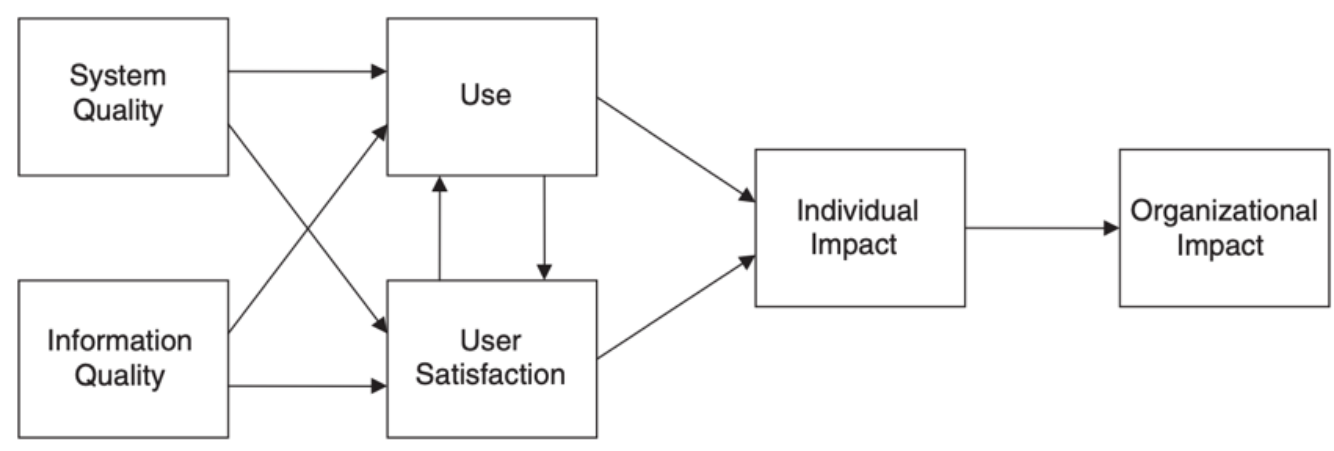

Figure 1 Information System Success Model (1992)

Consequently, DeLone and McLean modified their ISS model in 2003 by adding service quality factor into major quality components, system quality, and information quality, to enhance the measurement capability on the success of IS in e-commerce context (Figure 2). However, service quality is an insignificant determinant of behavioral intention (Brown \& Jayakody, 2008; Kuo, Wu, \& Deng, 2009). Tun (2020) also proved that service quality is not critical for mobile financial service adoption in Myanmar. Furthermore, Tam and Oliveira (2017) postulated that system quality and information quality could be the most significant quality dimensions to measure the success of an IS. Therefore, prior premise and research findings lead to exclude service quality construct in the research model.

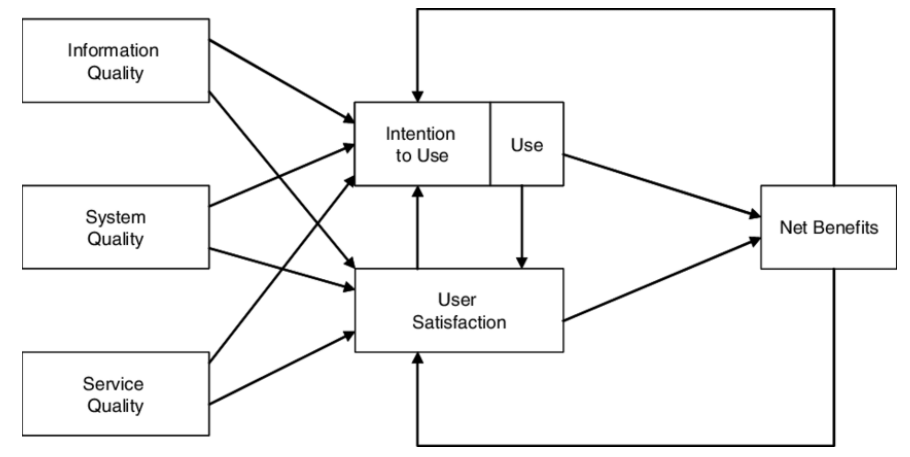

Figure 2 Updated Information System Success Model (2003)

Another significant modification in the updated D\&M ISS model (Figure 2) is the separation of use and intention to use. Venkatesh and Davis (1996) argued that users show their intention to use the technology before they use it by modifying Technology Acceptance Model (TAM). Fishbein and Ajzen (1975) explained that certain behavior of users originated from the intention for engaging by developing Theory of Reasoned Action (TRA) which is the background theory of TAM. Subsequently, DeLone and McLean (2003) proposed to separate 'intention to use' and 'use', but they are stuck to each other and alternation. Alam (2014) explicitly stated that behavioral intention is an unavoidable antecedent of actual adoption which is the ultimate business goal of banks. Therefore, the intention to adopt can be referred to as the willingness and possibility of the user to adopt a specific information system. The research model is adapted from DeLone and McLean (1992) as it focuses on investigating potential IS 
qualities that will lead to users' intention to adopt an IS, which does not predict its success. Moreover, none of the previous studies, as shown in Table 1, attempted to investigate the prerequisite of key IS quality factors of DeLone and McLean (1992).

Table 1 Summary of Relevant Previous Studies

\begin{tabular}{|c|c|c|c|c|}
\hline Researchers & Context & Country & $\begin{array}{l}\text { Sampling } \\
\text { Size }\end{array}$ & $\begin{array}{l}\text { Investigated IS } \\
\text { Qualities }\end{array}$ \\
\hline Sharma and Sharma (2019) & MB & Oman & 227 & SysQ, InfQ \\
\hline Lee and Chung (2009) & MB & Korea & 276 & SysQ, InfQ \\
\hline Myo and Hwang (2017) & MB & Myanmar & 206 & SysQ, InfQ \\
\hline $\begin{array}{l}\text { Deventer, Klerk, and Bevan-Dye } \\
\text { (2017) }\end{array}$ & MB & South Africa & 334 & SysQ \\
\hline Zhou (2011) & MB & China & 210 & SysQ, InfQ \\
\hline Zhou (2012) & MB & China & 240 & SysQ, InfQ \\
\hline Tam and Oliveira (2017) & MB & Southern European & 354 & SysQ, InfQ \\
\hline $\begin{array}{l}\text { Damabi, Firoozbakht, and } \\
\text { Ahmadyan (2018) }\end{array}$ & MB & Iran & 155 & SysQ, InfQ \\
\hline Lokman et al. (2017) & MB & Malaysia & 146 & SysQ, InfQ \\
\hline Chemingui and lallouna (2013) & $\begin{array}{l}\text { Mobile Financial } \\
\text { Services }\end{array}$ & Tunisia & 300 & SysQ \\
\hline Gao and Waechter (2017) & M-Payment & Australia & 851 & SysQ, InfQ \\
\hline Routray et al. (2019) & M-Wallet & India & 200 & SysQ, InfQ \\
\hline Koo, Wati, and Chung (2013) & $\begin{array}{l}\text { MB and Internet } \\
\text { Banking }\end{array}$ & Indonesia & 141 & SysQ, InfQ \\
\hline $\begin{array}{l}\text { Talukder, Quazi, and Sathye } \\
\text { (2014) }\end{array}$ & $\begin{array}{l}\text { Mobile Phone } \\
\text { Banking }\end{array}$ & Australia & 242 & SysQ \\
\hline Wilson and Mbamba (2017) & $\begin{array}{l}\text { Mobile Phone } \\
\text { Payment }\end{array}$ & Tanzania & 260 & SysQ \\
\hline Noh and Lee (2016) & $\begin{array}{l}\text { Mobile Apps-based } \\
\text { Banking }\end{array}$ & Korea & 520 & SysQ, InfQ \\
\hline Yoo (2020) & M-Commerce & Korea & 283 & SysQ, InfQ \\
\hline Phuong and Trang (2018) & M-Commerce & Vietnam & 427 & SysQ, InfQ \\
\hline Lee and Chen (2014) & M-Commerce & Taiwan & 406 & SysQ, InfQ \\
\hline $\begin{array}{l}\text { Yassierli, Vinsensius, and } \\
\text { Mohamed (2018) }\end{array}$ & M-Commerce & Indonesia & 230 & InfQ \\
\hline
\end{tabular}

\section{HYPOTHESES DEVELOPMENT}

\section{Device Quality}

The advanced mobile services such as carrying out financial transactions, seeking information, playing games, and buying and selling products can be accessed by using modern mobile devices (Roy, 2017). Likewise, Middleton (2010) stated that advanced technology has enabled mobile devices to have higher computing performance and network connectivity through wireless technologies such as $4 \mathrm{G}$, Wi-Fi and Bluetooth, which has led to the rise of mobile phone usage. Liu, Au and Choi (2014) explained that users can utilize mobile apps to perform desired functions by installing and running them on handheld devices such as tablets and mobile phones. The mobile device has unique features to influence users' beliefs and support special services for various businesses and information systems. Technically, the device quality could be investigated in three aspects: functionalities, compatibility, and 
performance. These aspects may have an impact on the perceptions of users, which in turn might outcome in the overall feeling of using the device (Parveen \& Sulaiman, 2008). Thus, previous literature leads to formulate the hypotheses:

H1: Device Quality has a significant positive effect on User Interface Design Quality.

H2: Device Quality has a significant positive effect on System Quality.

H3: Device Quality has a significant positive effect on Information Quality.

\section{User Interface Design Quality}

A higher quality of user interface design enables users to use desired functions on an information system in different approaches while being allowed to perceive the quality of the system (Branscomb \& Thomas, 1984). According to Jeong (2011), user interface design is referred as screen design, and Yoo (2020) considered it as visual quality. User interface design encompasses the whole visual appearance of information systems such as the font style, color usage, icons and buttons placement, and content layout (Graham, Hannigan, \& Curran, 2005). On the other hand, Bharati and Chaudhury (2004) stated that user interface design quality is the manner of displaying and presenting the information. Therefore, user interface design quality will be investigated as a discrete factor in the research although it is the sub-dimensions of system quality factor in D\&M ISS model (Seddon, 1997). The users will learn further about the information system based on their initial experience in user interface design (Everard \& Galletta, 2005). Lee and Chung (2009), Damabi, Firoozbakht, and Ahmadyan (2018) also proved that user interface design is a critical factor in mobile banking context. Therefore:

H4: User Interface Design Quality has a significant positive effect on System Quality.

H5: User Interface Design Quality has a significant positive effect on Information Quality.

\section{System Quality}

System quality is an instant impression through the using device that leads to use of the system since users do not directly access service in the case of MB (Gao \& Waechter, 2017). The extensive scope of system quality is obvious in the various ways measured by ease of use, functionality, usability, and response time of the specific system (DeLone \& McLean, 2003). System quality captures the concepts of the productivity model to evaluate the degree of IS resource, which is crucial in the mobile environment (Lee \& Chung, 2009). On the other hand, Kuan, Bock and Vathanophas (2008) stated that system quality is the technical perspective of the e-commerce system that produces information. Furthermore, Talukder, Quazi, and Sathye (2014) define system quality as the technological quality of the mobile system that reflects the quality of the information provided to users. Hariguna and Berlilana (2017), Sharkey, Scott, and Acton (2010), and Lin (2007) asserted that higher system quality has the capability to boost the intention of users to adopt it and lead to the rise of market share in the e-commerce landscape. Therefore, the hypotheses have been formulated: 
H6: System Quality has a significant positive effect on Information Quality.

H7: System Quality has a significant positive effect on intention to adopt MB.

\section{Information Quality}

Nelson, Todd, and Wixom (2005) defined information quality as a motivation factor, the information results or content of IS processing. Information quality is output of the system which represents how the information is organized on the limited user interface of a mobile device (Lee \& Chung, 2009). On the other hand, the measurements of information quality in e-commerce and traditional IS context are different because of their nature to reflect the objectivity, relevance, and reliability of the information (Yoo, 2020). Information quality can be considered as two dimensions: 1) intrinsic, where the information from the system represents the data of the real world, and 2) contextual, where the information is produced by the system after completing a specific process (McKnight et al., 2017). In addition, McKnight et al. (2017) stated that information qualities such as consistency, accuracy, and completeness can motivate the users to continue engaging the current services rather than the other services with inaccurate or incomplete information. Therefore, the following hypothesis can be proposed:

Hs: Information Quality has a significant positive effect on intention to adopt MB.

According to the prior research, theoretical background, and formulated hypotheses, the research model presented in Figure 3 with eight hypotheses and five constructs is proposed to validate in the research. Moreover, $\mathrm{H}_{2}, \mathrm{H}_{3}, \mathrm{H}_{4}$ and $\mathrm{H}_{5}$ are intended to answer RQ1, $\mathrm{H}_{1}$ and $\mathrm{H}_{6}$ are intended for RQ2, and RQ3 will be answered by $\mathrm{H}_{7}$ and $\mathrm{H}_{8}$.

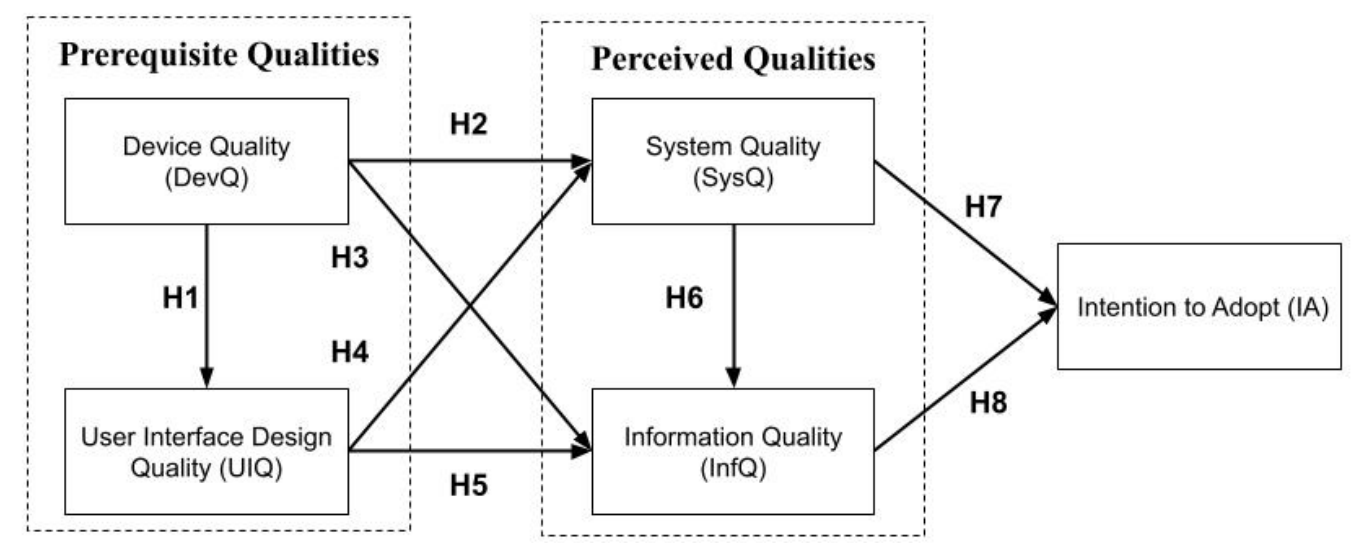

Figure 3: Proposed Research Model

\section{RESEARCH DESIGN}

Neuman (2006) recommended that the survey is an appropriate technique to understand attitudes and is suitable for quantitative research. Partly exploratory factor analysis (EFA) and 
partly confirmatory factor analysis (CFA), and structural equation modeling (SEM) analysis are employed and used to test the proposed hypotheses. The survey questionnaire (Appendix A) is developed in the bilingual language (English-Burmese) by using Google Form to collect data. The questionnaire is reviewed by five highly educated people with strong experience in using MB. The survey is conducted through social networking sites, Facebook and LinkedIn. All the indicators of factors (Table 2) in the questionnaire use a 5-point Likert scale ranging from 5 (strongly agree) to 1 (strongly disagree), except demographic variables. In the questionnaire, there is a filter question to ensure target participants are MB users of private commercial banks in Myanmar to reduce the rate of invalid dataset due to lack of knowledge regarding MB in general. According to SEM analysis, the widely accepted typical minimum sample size is 200. On the other hand, Kline (2011) suggested that sample size to the number of questionnaire items ratio (N:q) should be 20:1. Furthermore, Comrey and Lee (1992) recommend that the scale of sample size 500 is very good. Therefore, a minimum sampling size of 500 is required.

Table 2 Questionnaire Items of Factors

\begin{tabular}{lll}
\hline Factors & Items $(\mathrm{q}=15)$ & Reference \\
\hline Device Quality & DevQ1, DevQ2, DevQ3 & (Lu \& Su, 2009) \\
System Quality & SysQ1, SysQ2, SysQ3 & (Ahn, Ryu, \& Han, 2007) \\
Information Quality & InfQ1, InfQ2, InfQ3 & (Kim, Xu, \& Koh, 2004) \\
User Interface Design Quality & UI1, UI2, UI3 & (Lee \& Chung, 2009) \\
Intention to Adopt & IA1, IA2, IA3 & (Talukder, Quazi, \& Sathye, 2014) \\
\hline
\end{tabular}

\section{ANALYSIS RESULTS AND FINDINGS}

\section{Demographic Profile of the Respondents}

Total of 620 people in Myanmar responded to the questionnaire, 43 respondents (6.9\%) answered that they do not have prior experience in using MB, thus only 577 respondents are available for further data analysis. After eliminating outliers (12\%) from the remaining responses according to the value of standard deviation of each dataset, the valid dataset is down to 508. The final usable dataset consists of $41.3 \%$ male respondents and $58.7 \%$ female respondents, indicating that the result does not have gender bias. Most of the respondents $(71.1 \%)$ are the age group of 24-39 years (generation Y), followed by $18.9 \%$ above 40 years (generation $\mathrm{X}$ ), and $10 \%$ below 23 years old (generation $\mathrm{Z}$ ). In the survey, $66.3 \%$ respondents have higher than a bachelor degree and $31.1 \%$ respondents have a bachelor degree. Only $2.6 \%$ of respondents have a diploma and lower education level. Furthermore, half of the respondents $(50.2 \%)$ are civil-servant, $28 \%$ of participants are employees, and $10.8 \%$ are self-employed. Only $9.1 \%$ are students and $2.0 \%$ of respondents are unemployed. 
Table 3 Analysis Result of Demographic Profile of Respondents

\begin{tabular}{clcc}
\hline & Demographic & Freq $(\mathrm{N}=508)$ & Percentage \\
\hline \multirow{3}{*}{ Gender } & Male & 210 & $41.3 \%$ \\
& Female & 298 & $58.7 \%$ \\
& $<=23$ year & 51 & $10.0 \%$ \\
Age & 24-39 year & 361 & $71.1 \%$ \\
& $>=40$ year & 96 & $18.9 \%$ \\
& High School & 5 & $1.0 \%$ \\
& Diploma & 8 & $1.6 \%$ \\
& Bachelor Degree & 158 & $31.1 \%$ \\
& Master Degree & 286 & $56.3 \%$ \\
& Ph.D & 51 & $10.0 \%$ \\
& Employee & 142 & $28.0 \%$ \\
& Self-Employed & 55 & $10.8 \%$ \\
& Civil Servant & 255 & $50.1 \%$ \\
& Student & 46 & $9.1 \%$ \\
& Unemployed & 10 & $2.0 \%$ \\
\hline
\end{tabular}

\section{Preliminarily Descriptive Analysis}

First, preliminarily descriptive analysis is examined in SPSS software. All the questionnaire items of values of standard deviation, skewness, and kurtosis are between 2 and -2 according to the analysis results (Table 4). It indicates the normality of each questionnaire item and the contribution of respondents. Therefore, the dataset is suitable for the use of Maximum Likelihood (ML) estimation in SEM analysis (Kline, 2011). Table 4 shows that respondents strongly believe that their mobile phone has adequate features to perform well in conducting MB transactions and is compatible with MB (DevQ1, DevQ2, DevQ3). Furthermore, respondents have a positive belief that MB is easy to use (SysQ2) as it provides appropriate functionalities (SysQ1) for prompt financial transactions (SysQ3). Besides, the willingness of respondents to increase using MB (IA2) and to use MB whenever opportunities arising (IA3) are high.

Table 4 Preliminarily Descriptive Analysis Results

\begin{tabular}{ccccc}
\hline Items & Mean & Std. Deviation & Skewness & Kurtosis \\
\hline DevQ1 & 4.44 & 0.649 & -0.744 & -0.491 \\
DevQ2 & 4.48 & 0.626 & -0.796 & -0.376 \\
DevQ3 & 4.56 & 0.605 & $-1,018$ & 0.017 \\
SysQ1 & 4.25 & 0.730 & -0.617 & -0.268 \\
SysQ2 & 4.31 & 0.707 & -0.748 & 0.186 \\
SysQ3 & 4.07 & 0.707 & -0.370 & -0.118 \\
IA1 & 3.90 & 0.979 & -0.500 & -0.666 \\
IA2 & 4.14 & 0.827 & -0.601 & -0.444 \\
IA3 & 4.21 & 0.794 & -0.695 & -0.203 \\
InfQ1 & 3.82 & 0.773 & -0.138 & -0.495 \\
\hline
\end{tabular}


Table 4 Preliminarily Descriptive Analysis Results

(Continued)

\begin{tabular}{ccccc}
\hline Items & Mean & Std. Deviation & Skewness & Kurtosis \\
\hline InfQ2 & 3.75 & 0.783 & -0.054 & -0.55 \\
InfQ3 & 3.85 & 0.780 & -0.233 & -0.406 \\
UIQ1 & 3.84 & 0.766 & -0.068 & -0.630 \\
UIQ2 & 3.97 & 0.760 & -0.391 & -0.173 \\
UIQ3 & 3.94 & 0.800 & -0.438 & -0.212 \\
\hline
\end{tabular}

\section{Analysis Results of Factor Loading and Cronbach's Alpha}

Exploratory factor analysis (EFA) is conducted in SPSS software. Principal Components Analysis (PCA) method with a Varimax rotation of factor analysis is used to confirm that all the correspondence indicators are associated with respective factors from the proposed research model (Figure 3). All the indicators are with a loading coefficient greater than 0.5 (Hair et al., 2010) and the factor analysis confirms five factors affiliated from 15 indicators (Table 5). Furthermore, the analysis results of Cronbach's alpha of factors are greater than acceptable value 0.7 . The results indicate that internal consistency reliability is adequate (Table 5).

Table 5 Analysis Results of Factor Loading and Cronbach's Alpha

\begin{tabular}{|c|c|c|c|c|c|c|}
\hline & $\begin{array}{l}\text { Device } \\
\text { Quality }\end{array}$ & $\begin{array}{c}\text { Information } \\
\text { Quality }\end{array}$ & $\begin{array}{c}\text { Intention to } \\
\text { Adopt }\end{array}$ & $\begin{array}{c}\text { User Interface } \\
\text { Design Quality }\end{array}$ & $\begin{array}{l}\text { System } \\
\text { Quality }\end{array}$ & $\begin{array}{c}\text { Cronbach's } \\
\text { Alpha }\end{array}$ \\
\hline DevQ2 & 0.863 & 0.054 & 0.080 & 0.160 & 0.161 & \\
\hline DevQ1 & 0.809 & 0.212 & 0.121 & 0.045 & 0.100 & 0.833 \\
\hline DevQ3 & 0.799 & 0.041 & 0.183 & 0.158 & 0.209 & \\
\hline InfQ2 & 0.111 & 0.848 & 0.189 & 0.185 & 0.169 & \\
\hline InfQ1 & 0.087 & 0.772 & 0.191 & 0.195 & 0.266 & 0.851 \\
\hline InfQ3 & 0.159 & 0.751 & 0.186 & 0.294 & 0.165 & \\
\hline IA 2 & 0.137 & 0.178 & 0.831 & 0.193 & 0.200 & \\
\hline IA 1 & 0.190 & 0.146 & 0.816 & 0.172 & 0.077 & 0.828 \\
\hline IA3 & 0.091 & 0.226 & 0.769 & 0.179 & 0.236 & \\
\hline UIQ1 & 0.206 & 0.252 & 0.163 & 0.775 & 0.040 & \\
\hline UIQ2 & 0.099 & 0.211 & 0.218 & 0.760 & 0.296 & 0.813 \\
\hline UIQ3 & 0.101 & 0.204 & 0.202 & 0.747 & 0.273 & \\
\hline SysQ2 & 0.199 & 0.145 & 0.183 & 0.269 & 0.786 & \\
\hline SysQ3 & 0.117 & 0.352 & 0.171 & 0.212 & 0.710 & 0.779 \\
\hline SysQ1 & 0.361 & 0.206 & 0.219 & 0.111 & 0.629 & \\
\hline
\end{tabular}




\section{Correlations Among the Factors}

The relationships between the factors are investigated by using the matrices of Pearson correlation coefficients in SPSS software. The results confirmed that all the factors have significantly positive correlation with each other at a 0.01 level. Further, correlation coefficient ranging from 0.344 (DevQ $\leftrightarrow$ InfQ) to a maximum of 0.589 (SysQ $\leftrightarrow$ InfQ). The shaded cells in Table 6 represent the eight causal relationships in the proposed research model (Figure 3). However, the significant correlations do not confirm that there are significant causal effects between the factors (Kline, 2011).

Table 6 Analysis Result of Factor Correlations

\begin{tabular}{lccccc}
\hline Factors & DevQ & SysQ & IA & InfQ & UIQ \\
\hline Device Quality (DevQ) & 1 & & & & \\
System Quality (SysQ) & $0.503^{* *}$ & 1 & & & \\
Intention to Adopt (IA) & $0.377^{* *}$ & $0.524^{* *}$ & 1 & & \\
Information Quality (InfQ) & $0.344^{* *}$ & $0.589^{* *}$ & $0.499^{* *}$ & 1 & 1 \\
User Interface Design Quality (UIQ) & $0.381^{* *}$ & $0.582^{* *}$ & $0.512^{* *}$ & $0.584^{* *}$ & 1 \\
\hline
\end{tabular}

Note: **. Correlation is significant at the 0.01 level (2-tailed).

\section{The Results of Convergent Validity and Composite Reliability}

According to the procedures of CFA, reliability and convergent validity were examined by standardized regression weights, average variance extracted (AVE) and composite reliability (CR) by using AMOS software. The value of standardized regression weights for all indicators were greater than 0.691 and all the indicators are significant according to the suggestion of Hair et al. (2010). The acceptable threshold for CR value is $>0.7$ and for AVE is > 0.5. All the constructs of CR and AVE values exceeded their respective minimum acceptable values. Thus, the results indicate that the dataset has good internal consistency reliability and adequate convergent validity (Table 7).

Table 7 Analysis Results of Convergent Validity, AVE and CR

\begin{tabular}{ccccc}
\hline Factors & Items & $\begin{array}{c}\text { Std. Regression } \\
\text { Weights }\end{array}$ & CR & AVE \\
\hline \multirow{2}{*}{ Device Quality } & DevQ1 & 0.732 & 0.837 & 0.632 \\
& DevQ2 & 0.848 & & 0.547 \\
System Quality & DevQ3 & 0.800 & 0.783 & \\
& SysQ1 & 0.691 & & 0.662 \\
SysQ2 & SysQ3 & 0.778 & 0.747 & 0.854 \\
\hline
\end{tabular}


Table 7 Analysis Results of Convergent Validity, AVE and CR

(Continued)

\begin{tabular}{ccccc}
\hline & UIQ3 & 0.776 & & \\
User Interface Design Quality & UIQ2 & 0.837 & 0.817 & 0.599 \\
& UIQ1 & 0.703 & & \\
IA1 & 0.730 & & \multirow{2}{*}{0.837} \\
Intention to Adopt & IA2 & 0.840 & & \\
\hline
\end{tabular}

\section{The Result of Discriminant Validity}

Discriminant validity for the evaluation of the amount of difference among correlated constructs as defined by Hair et al. (2010) is always an important analysis to examine the validity of constructs. All the values of the square roots of the AVE are larger than the correlation estimates of each construct which demonstrate discriminant validity. In Table 8, all the values of the square root of AVE are bolded. According to the analysis results (Table 8), the proposed research model has satisfactory discriminant validity for further SEM analysis.

Table 8 Analysis Results of Discriminant Validity

\begin{tabular}{llllll}
\hline \multicolumn{1}{c}{ Factors } & DevQ & SysQ & InfQ & UIQ & IA \\
\hline Device Quality & $\mathbf{0 . 7 9 5}$ & & & & \\
System Quality & 0.601 & $\mathbf{0 . 7 4 0}$ & & & \\
Information Quality & 0.385 & 0.704 & $\mathbf{0 . 8 1 4}$ & & \\
User Interface Design Quality & 0.449 & 0.735 & 0.680 & $\mathbf{0 . 7 7 4}$ & $\mathbf{0 . 7 9 5}$ \\
Intention to Adopt & 0.433 & 0.645 & 0.585 & 0.616 & \\
\hline
\end{tabular}

\section{Model Fit Indices Analysis}

Verifying model fit indices is part of the CFA and the statistics for considered in this study are goodness of fit index (GFI), adjusted goodness of fit index (AGFI), normed fit index (NFI), incremental fit index (IFI), and comparative fit index (CFI). The fit indices of the measurement model obtained are as following: $\mathrm{x}^{2} / \mathrm{df}=2.055$; GFI $=0.960 ;$ AGFI $=0.939$; NFI $=0.958 ; \mathrm{IFI}=0.978 ; \mathrm{CFI}=0.978$ and RMSEA $=0.046$. The fit indices of structural model (research model) was further examined and the statistical results are: $\mathrm{x}^{2} / \mathrm{df}=2.126$; GFI $=$ 0.957; $\mathrm{AGFI}=0.937$; NFI $=0.955 ; \mathrm{IFI}=0.976$; $\mathrm{CFI}=0.976$ and $\mathrm{RMSEA}=0.047$. The values of GFI, AGFI, NFI, IFI and CFI of both measurement model and structural model are greater than recommended value of 0.90 and RMSEA is lower than 0.05 and hence these verification results (Table 9) confirm that the research model of this research is good-fit with dataset. 
Table 9 Analysis Result of Model Fit Indices

\begin{tabular}{lccccccc}
\hline & $\mathrm{x}^{2} / \mathrm{df}$ & GFI & AGFI & NFI & IFI & CFI & RMSEA \\
\hline Good-Fit & $<3$ & $>0.9$ & $>0.9$ & $>0.9$ & $>0.9$ & $>0.9$ & $<0.05$ \\
Measurement & 2.055 & 0.960 & 0.939 & 0.958 & 0.978 & 0.978 & 0.046 \\
Structural & 2.126 & 0.957 & 0.937 & 0.955 & 0.976 & 0.976 & 0.047 \\
\hline
\end{tabular}

\section{The Analysis Results of Hypotheses Testing}

The hypotheses were examined as proposed in Figure 3. The results of hypothesis testing are presented in Table 10 . Device quality positively affected user interface design quality $(\beta=0.589, \mathrm{p}<0.001)$ and system quality $(\beta=0.364, \mathrm{p}<0.001)$, which means that $\mathrm{H}_{1}$ and $\mathrm{H}_{2}$ are approved. User interface design quality positively affected system quality $(\beta=0.487$, $\mathrm{p}<0.001)$ and information quality $(\beta=0.340, \mathrm{p}<0.001)$. Thus, $\mathrm{H}_{4}$ and $\mathrm{H}_{5}$ are accepted. Furthermore, system quality $(\beta=0.593, p<0.001)$ evidenced a positive effect on information quality. Therefore, $\mathrm{H}_{6}$ is supported. System quality $(\beta=0.731, \mathrm{p}<0.001)$ and information quality ( $\beta=0.261, p<0.01$ ) with regard to $\mathrm{MB}$, showing a significant positive effect on the intention to adopt. Thus, $\mathrm{H}_{7}$ and $\mathrm{H}_{8}$ are consistent with the proposed hypotheses. However, the analysis result showed that the device quality has no significant effect on information quality which leads to rejection of $\mathrm{H}_{3}$. All the analysis results of hypothesis testing are concluded in Figure 4.

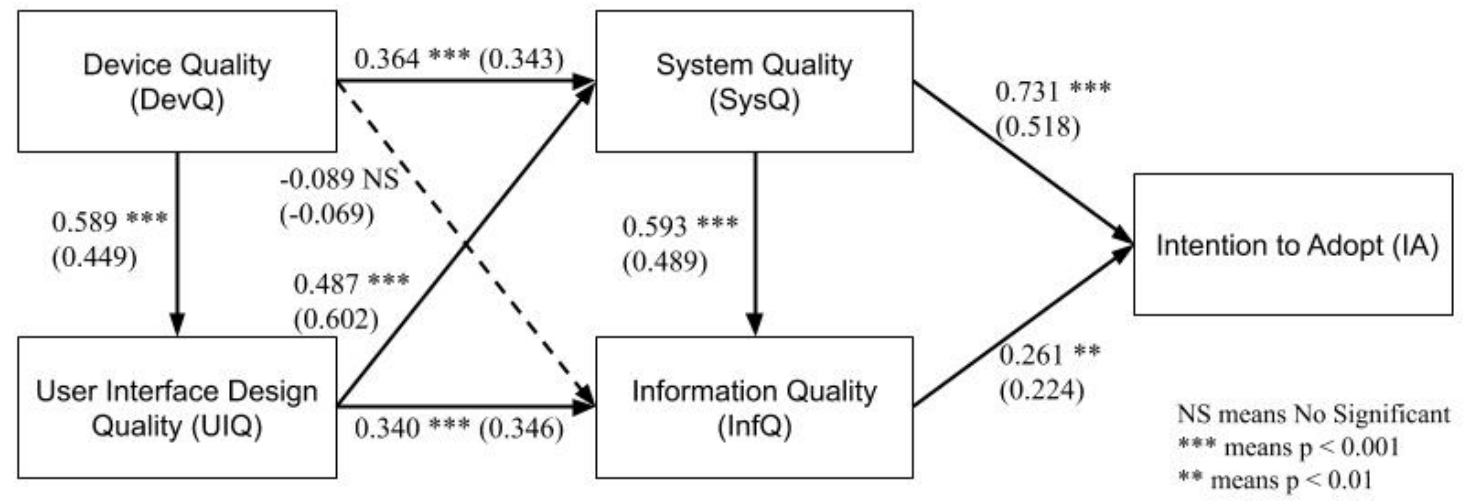

Figure 4 Research Model with Hypothesis Results

Table 10 Analysis Results of Hypotheses

\begin{tabular}{clcc}
\hline Hypothesis & \multicolumn{1}{c}{ Relationship } & Path Coefficient & Hypothesis Results \\
\hline H1 & DevQ $\rightarrow$ UIQ & $0.589 * * *(0.449)$ & Approved \\
H2 & DevQ $\rightarrow$ SysQ & $0.364 * * *(0.343)$ & Approved \\
H3 & DevQ $\rightarrow$ Inf & -0.089 NS $(-0.069)$ & Rejected \\
H4 & UIQ $\rightarrow$ SysQ & $0.487 * * *(0.602)$ & Approved \\
H5 & UIQ $\rightarrow$ InfQ & $0.340 * * *(0.346)$ & Approved \\
H6 & SysQ $\rightarrow$ InfQ & $0.593 * * *(0.489)$ & Approved \\
H7 & SysQ $\rightarrow$ IA & $0.731 * * *(0.518)$ & Approved \\
H8 & InfQ $\rightarrow$ IA & $0.261 * *(0.224)$ & Approved \\
\hline
\end{tabular}

Note: NS means No Significant, $* * *$ means $\mathrm{p}<0.001$, $* *$ means $\mathrm{p}<0.01$ 


\section{The Effects in the Research Model}

The shaded cells in Table 11 are additional findings of the research. An exogenous variable, device quality, has a higher effect on user interface design quality than system quality. Although device quality has no significant direct effect on information quality, it has a medium indirect effect through user interface design quality and system quality. User interface design quality has a medium effect on both system quality and information quality, and it is an intervening factor between device quality and information quality. Also, system quality has a medium effect on information quality. System quality and information quality have a direct effect on the intention to adopt construct, an endogenous variable, and system quality has a larger effect than information quality. Furthermore, both device quality and user interface design quality have medium indirect effects on intention to adopt through system quality.

Table 11 The Effects in the Research Model

\begin{tabular}{|c|c|c|c|c|c|c|}
\hline & \multirow{3}{*}{ Variables } & & \multicolumn{4}{|c|}{ Endogenous } \\
\hline & & & \multicolumn{3}{|c|}{ Intervening } & Dependent \\
\hline & & & UIQ & SysQ & InfQ & IA \\
\hline \multirow{7}{*}{ 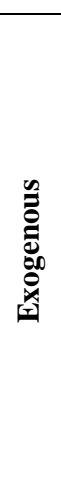 } & & & & & Indirectly Only & Indirect \\
\hline & Independent & DevQ & Direct & Direct & $\begin{array}{c}\operatorname{DevQ} \rightarrow \text { UIQ } \rightarrow \text { InfQ } \\
0.200^{* * *}(0.155)\end{array}$ & $\begin{array}{c}\mathrm{DevQ} \rightarrow \text { SysQ } \rightarrow \text { IA } \\
0.266 * * *(0.178)\end{array}$ \\
\hline & & & & & $\begin{array}{c}\mathrm{DevQ} \rightarrow \text { SysQ } \rightarrow \text { InfQ } \\
0.216^{* * *}(0.168)\end{array}$ & \\
\hline & \multirow{4}{*}{ Intervening } & & & & & Indirect \\
\hline & & UIQ & Nil & Direct & Direct & $\begin{array}{c}\mathrm{UIQ} \rightarrow \text { SysQ } \rightarrow \text { IA } \\
0.356^{* * *}(0.312)\end{array}$ \\
\hline & & SysQ & Nil & Nil & Direct & Direct \\
\hline & & InfQ & Nil & Nil & Nil & Direct \\
\hline
\end{tabular}

\section{THEORETICAL CONTRIBUTIONS}

The investigation on device quality and user interface design quality as a prerequisite of D\&M ISS model (1992) in the MB context is one of the novelties of this study. This study confirmed that underlying prerequisite qualities are existing and they are vivid requirements of information system success. The absolute qualities of the mobile device such as performance, functionality, and compatibility will help the users to interact with the MB comfortably through a user-friendly interface and learn the system quality effectively. Even experienced users are afraid that they will press the wrong buttons on complicated mobile applications during payment processes (Jarvenpaa \& Lang, 2005). Parveen and Sulaiman (2008) also stated that the smaller the screen size of mobile devices, the less information displayed. They further stated that better interface design and higher mobile device ability will lead to a positive belief of an individual that specific technology has adequate functionalities, fast response, and also easiness. According to the findings of this study, device quality will not increase the accessibility of sufficient and accurate real-time information. However, higher quality mobile 
devices are capable of delivering quality information through system quality and user interface design quality.

Further, the better quality of the mobile device is able to support the users to perceive the system quality of MB which will lead to the use of MB intensively. The comprehensive good design perspectives such as font, color, style, and shapes on the screen will allow users to access the full capacity of the MB system and acquire desired information from MB. Laukkanen (2007) also recommended larger screen size is required to display adequate financial information in the MB system. It can be implied that user interface design quality is a mediator between device quality and system quality. The appealing user interface design of MB will support users to have a good experience in system quality then it will encourage the users to keep using MB. The finding also indicates that system quality is able to deliver sufficient information whenever users need. In the banking industry, Ali and Ju (2019) advocated that a system with higher quality will provide more reliable and valid information for its users, in addition, if the system is easy to use and learn, the likelihood of users' adoption will high. Subsequently, perceived system quality and information quality will enhance the willingness of users to use MB frequently. Therefore, the findings are consistent with previous studies in mobile commerce and mobile banking context (Bahaddad, 2017; Noh \& Lee, 2016).

\section{MANAGERIAL CONTRIBUTIONS}

Bank managers should note that relying on existing IS quality factors for formulating MB system improvement strategy is not adequate. According to the findings, the better mobile device quality can display better quality of the image and higher screen resolution. Therefore, the users with the latest mobile device can enjoy the full capacity of the interface design of MB rather than the users with outdated mobile devices. MB is at a nascent phase most notably in Myanmar, MB must be easy to access and compatible with widely used mobile devices in the current market. Since user interface design quality has significant positive effects on both system quality and information quality, MB developers ought to ensure the interface of $\mathrm{MB}$ is simple, less complex and easy to interact with users by avoiding convoluted structures on the screen. Particularly in Myanmar, every text in MB is required to display in the native language properly and clearly, emphasize graphical user interface, and provide user guides to use of MB.

Therefore, users will get the best experience in system quality of MB and accessing the financial information through user interface design quality then MB adoption will follow. Banks should learn first about their customers' current performance of mobile phones before developing or releasing the new features for $\mathrm{MB}$, and ensure the forthcoming feature is compatible with the mobile phone the customers are currently using. Thus, it is imperative for software engineers to understand what improves system quality and information quality, how they are correlated, and how they drive the adoption of MB. Software engineers also should duly develop MB systems by strictly following the standardization of technical aspects of mobile technology because higher quality of system is still a competitive advantage in $\mathrm{MB}$ context notably in Myanmar. 


\section{CONCLUSIONS}

The research attempts to identify the underlying quality factors in information systems for the first time in MB context by utilizing D\&M ISS model (1992). The empirical findings suggest that IS qualities model incorporating additional prerequisite qualities, device quality and user interface design quality, is a stronger predictor for MB adoption among the customers of the private banks, thereby answering RQ1. Also, the research findings highlight essential quality factors for MB system development, upgrading features of $\mathrm{MB}$, and MB users' needs. In $\mathrm{MB}$ context, prerequisites of system quality are device quality and user interface design quality, system quality, and user interface design quality for information quality, thereby answering RQ2. In addition, the research concludes that system quality has a higher effect than information quality on $\mathrm{MB}$ adoption among the customers of private commercial banks, thereby answering RQ3. MB systems should be in harmony with mobile devices in the market and provide sufficient information as users require.

\section{LIMITATIONS AND FUTURE RESEARCH}

The major limitation of the research focuses on MB users only, and the perception of all the customers of private commercial banks does not reflect. Moreover, the opinion of generation $\mathrm{Y}$ is dominant in this study and the results may not be the same in generations $\mathrm{X}$ and $\mathrm{Z}$ who are with different experiences in the mobile technology landscape (Lin \& Theingi, 2019). These research findings are limited to a cross-sectional study, and a longitudinal approach incorporated with qualitative research is therefore recommended for future studies because the technology landscape is rapidly advancing and transforming over time. According to the contributions of the present study, future research can include device quality as a prerequisite of system quality, and user interface design quality is for information quality. Future researchers can extend the updated D\&M ISS model (2003) by supplementing the emerging factors of this study and should endeavor to investigate the underlying prerequisite of service quality. It is also recommended to validate the research model of this study in different contexts such as mobile learning, mobile commerce, and mobile services. Moreover, this research model can be reasonably extended by adding the role of the major device platforms (Android and IOS) as moderating variables for a deeper understanding of IS success in the mobile environment. 


\section{ACKNOWLEDGEMENTS}

First of all, I thank the Editor, Dr. Moch Faisal Karim, and anonymous reviewers for their constructive comments and suggestions on an earlier draft of the manuscript. I also thank Ms. Dior Liu, Ms. Sandi Myint Tun, my family, and my friends for all the encouragement they gave to me during this research. Special thanks to all the respondents for giving the answers to the questionnaires and those who gave extra support in making our work have a better quality.

\section{ABOUT THE AUTHORS}

Phyo Min Tun, B.A, M.I.S, and PhD (Assumption University of Thailand), has professional experience of more than 5 years in university lecturing and more than 7 years in digital marketing. Published 11 papers in international journals and conferences. His primary research interests are in the area of Banking, Mobile Financial Services, and Commerce.

\section{REFERENCES}

Ahn, T., Ryu, S., \& Han, I. (2007). The impact of Web quality and playfulness on user acceptance of online retailing. Information \& Management, 44(3), 263-275.

Alam, M. M. (2014). Factors Affecting Consumers' Adoption of Mobile Banking in Bangladesh: An Empirical Study. TNI Journal of Engineering and Technology, 2(2), 31-37.

AlBalawi, W., \& Rehman, I. H.-u. (2016). The Impacts of M-Commerce on Saudi Banks. Journal of Management and Strategy, 7(2), 1-8.

Ali, M., \& Ju, X. F. (2019). The Antecedents of Information System Success in The Banking Industry: An Empirical Investigation of The DeLone and McLean Model. International Journal of Management Science and Business Administration, 5(5), 43-58.

Bahaddad, A. A. (2017). Evaluating M-Commerce Systems Success: Measurement and Validation of the DeLone and McLean Model of IS Success in Arabic Society (GCC Case Study). Journal of Business Theory and Practice, 5(3), 156-193.

Bharati, P., \& Chaudhury, A. (2004). An Empirical Investigation of Decision-Making Satisfaction in Web-Based Decision Support Systems. Decision Support Systems, 37(2), 187-197.

Branscomb, L. M., \& Thomas, J. C. (1984). Ease of use: A system design challenge. IBM Systems Journal, 23(3), 224-235.

Brown, I., \& Jayakody, R. (2008). B2C e-Commerce Success: a Test and Validation of a Revised Conceptual Model. The Electronic Journal Information Systems Evaluation, 11(3), 167-184. 
Chemingui, H., \& lallouna, H. B. (2013). Resistance, motivations, trust and intention to use mobile financial services. International Journal of Bank Marketing, 31(7), 574-592.

Clarke III, I. (2001). Emerging Value Propositions for M-commerce. Journal of Business Strategies, 18(2), 133-148.

Comrey, A. L., \& Lee, H. B. (1992). A First Course in Factor Analysis (2 ${ }^{\text {nd }}$ ed.). Hillsdale, NJ: Lawrence Erlbaum.

Damabi, M., Firoozbakht, M., \& Ahmadyan, A. (2018). A Model for Customers Satisfaction and Trust for Mobile Banking Using DeLone and McLean Model of Information Systems Success. Journal of Soft Computing and Decision Support Systems, 5(3), 2128.

DeLone, W. H., \& McLean, E. R. (1992). Information systems success: The quest for the dependent variable. Information Systems Research, 3(1), 60-95.

DeLone, W., \& McLean, E. (2003). The DeLone and McLean model of information systems success: A ten-year update. Journal of Management Information Systems, 19(4), 9-30.

Deventer, M. v., Klerk, N. d., \& Bevan-Dye, A. (2017). Antecedents of attitudes towards and usage behavior of mobile banking amongst Generation Y students. Banks and Bank Systems, 12(2), 78-90.

Everard, A., \& Galletta, D. F. (2005). How Presentation Flaws Affect Perceived Site Quality, Trust, and Intention to Purchase from an Online Store. Journal of Management Information Systems, 22(3), 56-95.

Fishbein, M., \& Ajzen, I. (1975). Belief, attitude, intention and behaviour: An introduction to theory and research. MA: Addison-Wesley.

Gao, L., \& Waechter, K. A. (2017). Examining the role of initial trust in user adoption of mobile payment services: an empirical investigation. Information Systems Frontiers, 19(3), 525-548.

Graham, M., Hannigan, K., \& Curran, P. (2005). Imagine: Visual Design in First-Year Composition. Journal of Visual Literacy, 25(1), 21-40.

Gu, J.-C., Lee, S.-C., \& Suh, Y.-H. (2009). Determinants of behavioral intention to mobile banking. Expert Systems with Applications, 36(9), 11605-11616.

Hair, J., Black, W., Babin, B., \& Anderson, R. (2010). Multivariate Data Analysis (7 $7^{\text {th }}$ ed.). Upper Saddle River, NJ: Prentice-Hall, Inc.

Hariguna, T., \& Berlilana, B. (2017). Understanding of Antecedents to Achieve Customer Trust and Customer Intention to Purchase E-Commerce in Social Media, an Empirical Assessment. International Journal of Electrical and Computer Engineering, 7(3), 1240-1245. 
Hofmann, A. (2018). Myanmar's Banking Sector in Transition Current Status and Challenges Ahead. Bonn and Eschborn, Germany: Internationale Zusammenarbeit (GIZ) GmbH.

Jarvenpaa, S., \& Lang, K. (2005). Managing the paradoxes of mobile technology. Information Systems Management, 22(4), 7-23.

Jeong, B.-K., \& Yoon, T. E. (2013). An Empirical Investigation on Consumer Acceptance of Mobile Banking Services. Business and Management Research, 2(1), 31-40.

Jeong, H. (2011). An investigation of user perceptions and behavioral intentions towards the e-library. Library Collections Acquisitions and Technical Services, 35(2), 45-60.

Kemp, S. (2020). DIGITAL 2020: MYANMAR. DataReportal.

Kim, G., Shin, B., \& Lee, H. G. (2009). Understanding dynamics between initial trust and usage intentions of mobile banking. Information Systems Journal, 19(3), 283-311.

Kim, H., Xu, Y., \& Koh, J. (2004). A comparison of online trust building factors between potential customers and repeat customers. Journal of the Association for Information Systems, 5(10), 392-420.

Kline, R. B. (2011). Principles and Practice of Structural Equation Modeling ( $3^{\text {rd }}$ ed.). New York, NY: The Guilford Press.

Koo, C., Wati, Y., \& Chung, N. (2013). A Study of Mobile and Internet Banking Service: Applying for IS Success Model. Asia Pacific Journal of Information Systems, 23(1), 65-86.

Kuan, H. H., Bock, G. W., \& Vathanophas, V. (2008). Comparing the effects of website quality on customer initial purchase and continued purchase at e-commerce websites. Behavior \& Information Technology, 27(1), 3-16.

Kuo, Y.-F., Wu, C.-M., \& Deng, W.-J. (2009). The relationships among service quality, perceived value, customer satisfaction, and post-purchase intention in mobile valueadded services. Computers in Human Behavior, 25(4), 887-896.

Laukkanen, T. (2007). Internet vs mobile banking: Comparing customer value perceptions. Business Process Management Journal, 13(6), 788-797.

Lee, H.-M., \& Chen, T. (2014). Perceived Quality as A Key Antecedent in Continuance Intention on Mobile Commerce. International Journal of Electronic Commerce Studies, 5(2), 123-142.

Lee, K. C., \& Chung, N. (2009). Understanding factors affecting trust in and satisfaction with mobile banking in Korea: A modified DeLone and McLean's model perspective. Interacting with Computers, 21(5-6), 385-392 . 
Lin, H.-F. (2007). The Impact of Website Quality Dimensions on Customer Satisfaction in the B2C E-commerce Context. Total Quality Management \& Business Excellence, 18(4), 363-378.

Lin, Z., \& Theingi, H. (2019). Extended UTAUT2 Model on Factors Influencing of Mobile Commerce Acceptance in Yangon, Myanmar. AU-GSB e-Journal, 12(2), 3-18.

Liu, C. Z., Au, Y. A., \& Choi, H. S. (2014). Effects of freemium strategy in the mobile app market: An empirical study of google play. Journal of Management Information Systems, 31(3), 326-354.

Lokman, A. M., Rosely, N. R., Aziz, A. A., \& Mokhsin, M. (2017). Trust in Mobile Banking based on DeLone \& McLean IS Success Model. International Journal of Control Theory and Applications, 10(25), 299-306.

Lu, H.-P., \& Su, P. Y.-J. (2009). Factors affecting purchase intention on mobile shopping web sites. Internet Research, 19(4), 442-458.

Lwin, N., Ameen, A., \& Nusari, M. (2019). Mobile Banking Adoption among Customers within Private Commercial Banking Sector in Yangon, Myanmar. International Journal of Management and Human Science, 3(2), 44-59.

Mahad, M., Mohtar, S., Yusoff, R. Z., \& Othman, A. A. (2015). Factor Affecting Mobile Adoption Companies in Malaysia. International Journal of Economics and Financial Issues, 5(1), 84-91.

McKnight, D. H., Lankton, N. K., Nicolaou, A., \& Price, J. (2017). Distinguishing the effects of B2B information quality, system quality, and service outcome quality on trust and distrust. The Journal of Strategic Information Systems, 26(2), 118-141.

Middleton, C. (2010). Delivering Services over Next Generation: Broadband Networks. Telecommunications Journal of Australia, 60(4), 59-71.

Myo, S. T., \& Hwang, G.-H. (2017). Effect of Mobile Devices on the Use Intention and Use of Mobile Banking Service in Myanmar. Journal of Digital Convergence, 15(6), 7182.

Nelson, R. R., Todd, P. A., \& Wixom, B. H. (2005). Antecedents of Information and System Quality: An Empirical Examination within the Context of Data Warehousing. Journal of Management Information Systems, 21(4), 199-235.

Neuman, W. L. (2006). Social research methods : qualitative and quantitative approaches $\left(6^{\text {th }}\right.$ ed.). Boston: Sage, Allyn and Bacon.

Noh, M. J., \& Lee, K. T. (2016). An analysis of the relationship between quality and user acceptance in smartphone apps. Information Systems and e-Business Management, 14(2), 273-291. 
Parveen, F., \& Sulaiman, A. (2008). Technology Complexity, Personal Innovativeness And Intention To Use Wireless Internet Using Mobile Devices In Malaysia. International Review of Business Research Papers, 4(5), 1-10.

Petter, S., DeLone, W., \& McLean, E. R. (2013). Information Systems Success: The quest for the independent variables. Journal of Management Information Systems, 29(4), 7-62.

Phuong, N. N., \& Trang, T. T. (2018). Repurchase Intention: The Effect of Service Quality, System Quality, Information Quality, and Customer Satisfaction as Mediating Role: A PLS Approach of M-Commerce Ride Hailing Service in Vietnam. Marketing and Branding Research, 5(2), 78-91.

Routray, S., Khurana, R., Payal, R., \& Gupta, R. (2019). A Move towards Cashless Economy: A Case of Continuous Usage of Mobile Wallets in India. Theoretical Economics Letters, 9(4), 1152-1166.

Roy, S. (2017). App Adoption and Switching Behavior: Applying the Extended Tam in Smartphone App Usage. Journal of Information Systems and Technology Management, 14(2), 239-261.

Seddon, P. B. (1997). A Respecification and Extension of the DeLone and McLean Model of IS Success. Information Systems Research, 8(3), 240-253.

Shannon, C. E., \& Weaver, W. (1949). The Mathematical Theory ofCommunication. Urbana Illinois: University of Illinois Press.

Sharkey, U., Scott, M., \& Acton, T. (2010). The Influence of Quality on E-Commerce Success: An Empirical Application of the Delone and Mclean IS Success Model. International Journal of E-Business Research, 6(1), 68-84.

Sharma, S. K., \& Sharma, M. (2019). Examining the role of trust and quality dimensions in the actual usage of mobile banking services: An empirical investigation. International Journal of Information Management, 44, 65-75.

Talukder, M., Quazi, A., \& Sathye, M. (2014). Mobile Phone Banking Usage Behaviour: An Australian Perspective. Australasian Accounting, Business and Finance Journal, 8(4), 83-104.

Tam, C., \& Oliveira, T. (2017). Understanding mobile banking individual performance The DeLone \& McLean model and the moderating effects of individual culture. Internet Research, 27(3), 538-562.

Tun, P. M. (2020). An Investigation of Factors Influencing Intention to Use Mobile Wallets of Mobile Financial Services Providers in Myanmar. The Asian Journal of Technology Management, 13(2), 129-144. 
Tun, P. M. (2020a). Factors Influencing Intention to Reuse Mobile Banking Services for the Private Banking Sector in Myanmar. ASEAN Journal of Management \& Innovation, 7(1), 63-78.

Turnell, S. (2011). Fundamentals of Myanmar's Macroeconomy: A Political Economy Perspective. Asian Economic Policy Review, 6, 136-153.

Venkatesh, V., \& Davis, F. D. (1996). A Model of the Antecedents of Perceived Ease of Use: Development and Test. Decision Sciences, 27(3), 451-481.

Wilson, V., \& Mbamba, U. (2017). Acceptance of Mobile Phone Payments Systems in Tanzania: Technology Acceptance Model Approach. Business Management Review, 20(2), 15-25.

Yassierli, Y., Vinsensius, V., \& Mohamed, M. S. (2018). The Importance of Usability Aspect in M-Commerce Application for Satisfaction and Continuance Intention. Makara Journal of Technology, 22(3), 149-158.

Yeo, J. H., \& Fisher, P. J. (2017). Mobile Financial Technology and Consumers' Financial Capability in the United States. Journal of Education \& Social Policy, 7(1), 80-93.

Yoo, J. (2020). The Effects of Perceived Quality of Augmented Reality in Mobile Commerce - An Application of the Information Systems Success Model. Informatics, 7(2), 1-14.

Zhou, T. (2011). An empirical examination of initial trust in mobile banking. Internet Research, 21(5), 527-540.

Zhou, T. (2012). Understanding users' initial trust in mobile banking: An elaboration likelihood perspective. Computers in Human Behavior, 28(4), 1518-1525. 


\section{APPENDIX}

\begin{tabular}{cl}
\hline Items & \\
\hline DevQ1 & My mobile phone has adequate features to support MB. \\
DevQ2 & $\begin{array}{l}\text { My mobile phone performs well while conducting financial transactions } \\
\text { with MB. }\end{array}$ \\
DevQ3 & My mobile phone is compatible with MB. \\
SysQ1 & MB provides a fast response and transactions processing. \\
SysQ2 & MB is easy to use. \\
SysQ3 & MB offers appropriate functionalities. \\
IA1 & I plan to use MB frequently in my daily life. \\
IA2 & I intend to increase my use of MB. \\
IA3 & I intend to use MB when the opportunity arises. \\
InfQ1 & MB provides me with information relevant to my needs. \\
InfQ2 & MB provides me with sufficient information. \\
InfQ3 & MB provides me with accurate information. \\
UIQ1 & The screen colors used for MB are appropriate. \\
UIQ2 & The presentation style of MB is easy to understand. \\
UIQ3 & MB is easy to navigate. \\
\hline
\end{tabular}

